\title{
MORPHOMETRIC AND LAND USE ANALYSIS TO ESTIMATE FLOOD HAZARD - A CASE STUDY OF UPPER CIMANUK WATERSHED IN GARUT REGENCY, INDONESIA
}

\author{
*Denny Lumban Raja ${ }^{1,2}$, Emi Sukiyah ${ }^{3}$, Nana Sulaksana ${ }^{4}$, and Cipta Endyana ${ }^{4}$ \\ ${ }^{1}$ Doctoral Program of Geological Engineering, Universitas Padjadjaran, Bandung; Indonesia \\ ${ }^{2}$ Human Resource Development Center for Geology, Mineral, and Coal, Bandung, Indonesia \\ ${ }^{3}$ Department of Geoscience, Universitas Padjadjaran, Bandung, Indonesia \\ ${ }^{4}$ Department of Applied Geology, Universitas Padjadjaran, Bandung, Indonesia
}

*Corresponding Author, Received: 06 March 2020， Revised: 02 April 2020， Accepted: 26 April 2020

\begin{abstract}
Flood is one of the most common hazards and the events have often occurred in the Garut Regency, which can cause loss of property and human lives. Eighteen-four sub-watersheds has divided The Upper Cimanuk Watershed based on three-order, selected as DTA01 to DTA84, for prioritization purpose. In this study a flood hazard model in Upper Cimanuk watershed is examined based on the morphometric aspect, combined land use analysis and the supplementary information regarding slope and rainfall. Each sub-drainage basin was ordered into grades based on the considered compound parameter (Cp). These results define the area flood hazard in prioritization map were divided into three zones: high, medium and low classes. Three distinct measurements such as basic, linear (Rb, Dd, Lof, and T), and shape (Re and Rf) aspects obtained the morphometric characterization over the 84 sub-watersheds. The prioritization results based on the connection of morphometric aspects and land use only 12 sub-drainage basin considered as First priority, 9 sub-watersheds considered as medium and 5 sub-watersheds considered as low priority. The result of this study can exact the action to fix the possible hazard from floods in the study area.
\end{abstract}

Keywords: Morphometric analysis, Land use, Prioritization, Geographic information system, Remote sensing, Flood, Cimanuk watershed

\section{INTRODUCTION}

Indonesia is known as a disaster prone country due to geographical, geological and demographical conditions. According to the Indonesian National Board for Disaster Management, more than 98\% of disaster occurs (January-September 2019) is hydro meteorological hazard such as a flood.

Flood is a natural phenomenon that occurs when the intensity of falling rain is very high, while the soil is not able to absorb it well and then runoff occurs. The upstream part of the watershed characteristics associated with flood problems in the downstream, especially to prevent erosion and sedimentation.

Land use variations from vegetation to nonvegetation, forest exploitation and added to heavy rainfall in the upper Cimanuk watershed affect the continuity of the hydrological, erosion and sedimentation process leading cause of drainage basin loss of water retention and improved surface runoff and flood release. All those conditions indicated of flood events that occurred in Garut Regency on 20th September 2016. This flood caused demise or wound to human and impairment loss of valuable belongings, ecosystem, infrastructure, communication scheme, agricultural terrestrial, forest, natural environment, etc. According to Indonesia's National Agency of Disaster Mitigation there are 40 people died, 20 people missing, 6361 people evacuated and suffered the loss for 288 billion rupiahs.

There are several studies in this area have been led related to the geological, tectonic, land use, and erosion such as [1-5]. In numerous articles, morphometric studies were castoff for basin Classification, it explains that morphometric is the quantity and mathematic investigation the outline of the outside earth, form, and dimension of its landforms [6]. The calculation of linear, aerial and relief aspects could achieve the analyst of the basin.

Watershed morphometric analysis offers a measurable explanation of the drainage organization. It is an important point from the watershed characters [7]. New progress on the morphometric aspect of the drainage basin has been approved by $[7,8]$ and others. Morphometric parameters of some watersheds showed vital role in prioritization of sub-watershed [9]

The remote sensing and GIS stuff was used for basin analysis from basin morphometric. In the present-day learning, sub-watersheds of Cimanuk River in Garut Regency, West Java has accepted examination of morphometric, rainfall, slope, land use/ land use to calculate the main priority of 
watershed using GIS stuff and remote sensing for manage flood, so the flood will not recur. Appropriate measures can be helped these results to fix the probable hazards from floods in the area with prioritization.

\section{STUDY AREA \& DATA USED}

The basin research area is unique from the major drainage systems basin in West Java with a catchment area of 3,752 sq. km. Cimanuk is unique of the six main streams in West Java, (the others are Citarum, Ciliwung, Cisadane, Cimandiri, and Citandui), flowing from the mountainous zone of Garut, the Cikurai highland, transitory through Sumedang and Majalengka extents and over in the coastal area of Indramayu (the Java Sea). The length of this river is approximately $175 \mathrm{~km}$ with the width varies from about $6 \mathrm{~m}$ upstream to about $150 \mathrm{~m}$ downstream.

The study area is located in Upper Cimanuk Catchment Area. Located at $107^{\circ} 42^{\prime} 21^{\prime \prime} \mathrm{E}-107^{\circ}$ 58 ' $32^{\prime \prime} \mathrm{E}$ and $7^{\circ} 7^{\prime} 4^{\prime \prime} \mathrm{S}-7^{\circ} 24^{\prime} 45^{\prime}$ ' $\mathrm{S}$, it has on area about $448.6 \mathrm{sq}$. $\mathrm{km}$. The elevation research area diverges from 740 to $1040 \mathrm{~m}$ above MSL (mean sea level). Administratively the study area belongs to Garut Regency as shown in Figure 1.

The stream and drainage basin of the research area was extracted from topographic maps with 1:25.000 scale (12.5 m contour interval) from was published by Geospatial Information Agency of Indonesia. Furthermore, the digital elevation model and slope map were created from ASTER DEM with $10 \mathrm{~m}$ spatial resolution.

Geomorphological, upper Cimanuk drainage basin differs from highlands and mounts and also controlled by active tectonic [1]. Daily rainfall data was composed of the Climatology and Geometeorology Agency of Indonesia and the data hail from six precipitation stations. LANDSAT 8 was used to bring out a land use.

\section{METHODOLOGY}

GIS and Remote sensing techniques were being used for rainfall, land use, slope, and quantitative morphometric analysis of basin simultaneously. Flow sequence was set using the flow ordering system given by $[8,10]$. Processing and analysis of drainage network data was carried out using GIS software. The drainage network has demarcated the sub-watershed boundary network under third order and classified into 84 (eighty-four) sub-watersheds.

GIS software has been used to calculate five spatial parameters of morphometric which are the length of the basin $(\mathrm{Lb})$, area $(\mathrm{A})$, perimeter $(\mathrm{P})$, length of streams ( $\mathrm{Lu})$ and stream order $(\mathrm{Nu})$. Subsequently, the obtained parameters are used for analyze the morphometric properties of the research

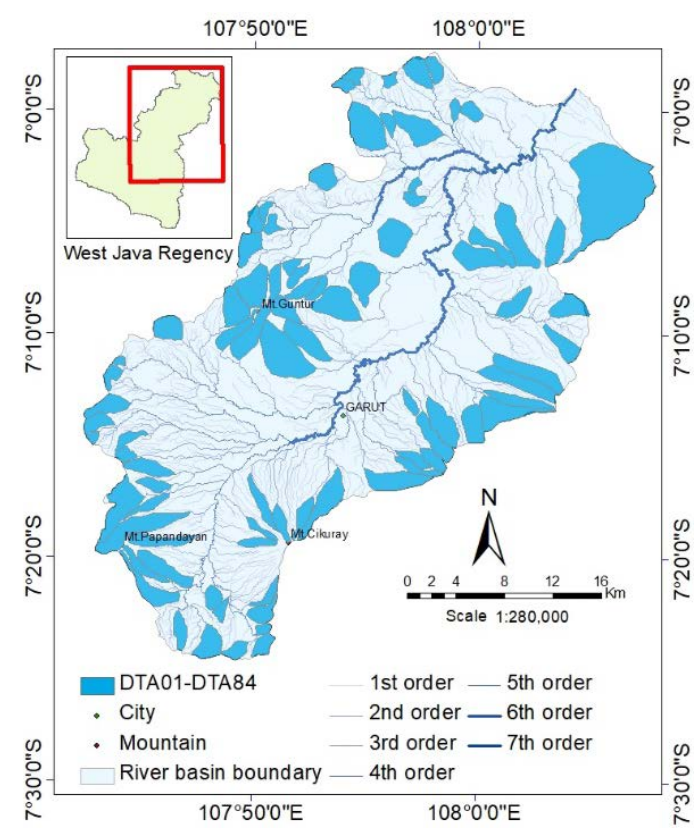

Fig. 1. The upper Cimanuk watershed research area in Garut Regency, West Java

area. Those properties are density of drainage (Dd), ratio of bifurcation (Rb), overland flow length (Lof), the ratio of texture (T), ratio of elongation (Re) and the ratio of relief $(\mathrm{Rh})$ that were developed by $[8,11,12]$ (Table 1).

Table 1. Computation of morphometric parameters.

\begin{tabular}{|c|c|c|}
\hline $\begin{array}{l}\text { Morphometric } \\
\text { Parameter }\end{array}$ & Formula & References \\
\hline \multicolumn{3}{|l|}{ Basic } \\
\hline $\begin{array}{l}\text { Area of Basin } \\
\text { (A) }\end{array}$ & $\begin{array}{l}\text { Plan area of the } \\
\text { watershed (sq.km) }\end{array}$ & [8] \\
\hline $\begin{array}{l}\text { Perimeter of } \\
\text { Basin (P) }\end{array}$ & $\begin{array}{l}\text { Perimeter of watershed } \\
\qquad(\mathrm{km})\end{array}$ & [8] \\
\hline $\begin{array}{l}\text { Basin Length } \\
\text { (Lb) }\end{array}$ & $\begin{array}{c}\mathrm{Lb}=1.321 \times \mathrm{A} 0.568 \mathrm{.} \\
\text { where } \\
\mathrm{A}=\text { Area of Basin } \\
(\mathrm{sq} . \mathrm{km})\end{array}$ & {$[11]$} \\
\hline $\begin{array}{l}\text { Stream Order } \\
\quad(\mathrm{Nu})\end{array}$ & Hierarchical rank & [8] \\
\hline $\begin{array}{l}\text { Stream Length } \\
\text { (Lu) }\end{array}$ & $\begin{array}{l}\text { Length of the Stream } \\
\qquad(\mathrm{km})\end{array}$ & [8] \\
\hline \multicolumn{3}{|l|}{ Linear } \\
\hline $\begin{array}{l}\text { Bifurcation Ratio } \\
\text { (Rb) }\end{array}$ & $\mathrm{Rb}=\mathrm{Nu} / \mathrm{Nu}+1$, where & [8] \\
\hline $\begin{array}{l}\text { Drainage density } \\
\text { (Dd) }\end{array}$ & $\begin{array}{l}\mathrm{Nu}+1=\text { no. of segments } \\
\text { of the next higher order }\end{array}$ & [8] \\
\hline Texture ratio $(\mathrm{T})$ & $\mathrm{Dd}=\mathrm{Lu} / \mathrm{A}$, Where & [8] \\
\hline $\begin{array}{l}\text { Length of } \\
\text { overland flow } \\
\text { (Lof) }\end{array}$ & $\begin{array}{l}\mathrm{Lu}=\text { total stream length } \\
\text { of all orders }(\mathrm{km})\end{array}$ & [8] \\
\hline \multicolumn{3}{|l|}{ Shape } \\
\hline Form Factor (Rf) & $\begin{array}{c}\mathrm{Rf}=\mathrm{A} / \mathrm{Lb}^{2} \text {, where } \\
\mathrm{A}=\text { Area of the } \\
\text { Basin }(\mathrm{sq} \cdot \mathrm{km}) \\
\mathrm{Lb}=\text { Basin Length }(\mathrm{km}) \text {, }\end{array}$ & [8] \\
\hline $\begin{array}{l}\text { Elongation Ratio } \\
\text { (Re) }\end{array}$ & $\begin{array}{c}\mathrm{Re}=1.128 \mathrm{~A}^{0.5} / \mathrm{Lb}, \\
\text { where } \\
\mathrm{A}=\text { Area of the } \\
\text { Basin }(\mathrm{sq} . \mathrm{km}) \\
\mathrm{Lb}=\text { Basin Length }(\mathrm{km})\end{array}$ & [12] \\
\hline
\end{tabular}


Image-based sorting for land use/land use remained shown by put on the maximum probability classifier of supervised classification LANDSAT 8 (2019). It was compiled using Arc GIS platform as shown in Figure 4. Additionally, of map of the slope aspect was generated from ASTER DEM as base data as that shown below Figure 2 .

A relative weighting assignment system has adopted to evolve at compound value [13]. The parameter of the lowest compound value has the priority from the sub-watershed. To control the flood threat intermission class, we use calculation, Equation 1 as presented by [14].

$$
\mathrm{I}=\frac{\mathrm{c}-\mathrm{b}}{\mathrm{k}}
$$

Where:

I: the distance interval class

c: the highest score

b: the lowest score

$\mathrm{k}$ : the class desired

\section{RESULT AND DISCUSSION}

GIS environment has brought out a morphometric explanation of all the subwatersheds. The calculation of all watershed is 1134 , $61 \mathrm{sq}$. $\mathrm{km}$ with a perimeter (P) of $174.54 \mathrm{~km}$ and the length is $143.8 \mathrm{~km}$. The flood hazard level of each watershed is represented by eleven morphometrical properties.

\subsection{Morphometric Analysis}

\subsubsection{Basic morphometric parameters}

Dimensions of the basin research area are corresponding possible run-off water volume of its basin that yielded by precipitation. DTA46 has a minimum area of $0.59 \mathrm{sq}$. $\mathrm{km}$ with the shortest river length of $2.5 \mathrm{~km}$. While DTA71 has the maximum area of $39.86 \mathrm{sq}$. $\mathrm{km}$ with the longest river length is $68.36 \mathrm{~km}$.

The watershed perimeter represents watershed size and shape. DTA71 has a maximum perimeter of $30.027 \mathrm{~km}$ and DTA73 has a minimum perimeter $3.683 \mathrm{~km}$. Calculated distance and quantity of stream sections for eighty-four sub-watersheds.

\subsubsection{Bifurcation ratio $(R b)$}

Horton (1945) measured bifurcation ratio as guide of reliefs and segmentations. The normal bifurcation ratios $(\mathrm{Rb})$ range between 3.0 to 5.0 mirror that geological structures don't impact the drainage. The lower values of the bifurcation ratio indicate less structural disturbance and less distortion in the drainage pattern [10].

High $\mathrm{Rb}$ values indicate young hydrograph crowning with a superior latent of the prospect for flash inundating in the thunderstorm [15]. Tectonic active area and strong structural pattern were suggested by a higher bifurcation ratio. In the present study, the majority of bifurcation ratio $(\mathrm{Rb})$ of sub-watersheds is less than 5 (1.04 to 4.63).

The highest bifurcation ratio value is 4.63 located on sub-watershed DTA12, DTA49, and DTA84. Otherwise, sub-watershed DTA27 has the lowest bifurcation ratio value 1.04. Bifurcation ratio $(\mathrm{Rb})$ value for the entire Cimanuk subwatersheds is 2.33 and it is relatively low.

\subsubsection{Density of drainage basin (Dd)}

Dd represents disparity between drainage area and it's stream length [8]. A high Dd value frequently occur in the area of relatively high impermeable, sparse vegetation, mountainous relief, high runoff, low infiltration, and erosion latent of the basin research area. Conversely, low drainage density of a basin implies permeable soil that high resistance below dense vegetative cover, low relief, low runoff and high infiltration $[10,16]$.

The drainage density (Dd) for the entire Upper Cimanuk Sub-watershed is $3.33 \mathrm{~km} / \mathrm{sq}$. km, and for the 84 sub-basins varies from 1.59 for subwatershed DTA66 to $5.21 \mathrm{~km} / \mathrm{sq}$. km for subwatershed DTA11, considered as a medium category which designates gentle to steep slope terrain, medium dense vegetation, less permeable and medium infiltration, and surface runoff.

\subsubsection{Elongation ratio $(\mathrm{Re})$}

The Re explains the ratio from the distance of the sphere of the equal area as the drainage basin and the determined basin length [17]. Elongation Ratio ( $\mathrm{Re}$ ) is a more substantial index in the basin shape analysis and characters of drainage basin hydrology. The common Re values range between 0.6 and 1.0 over a variety of geology and climate types [10]. The higher elongation ratio values indicate infiltrate with high capacity and low runoff. High susceptibility characterizes the lower Re values to erosion and sediment load [18].

Elongation ratio values close to 1.0 usually occur in the areas of very low relief, in which the value range from $0.6-0.8$, high relief and steep ground slope [10]. The elongation ratio $(\mathrm{Re})$ values in the study area are ranging between 0.665 (subwatershed DTA71) to 0.886 (sub-watershed DTA46). It indicates the research area has a steep ground slope, high relief, low infiltration, and high runoff.

\subsubsection{Form factor $(R f)$}

Area basin ratio defines the form factor to the 
square of the basin length [8]. The point of form factor with less than 0.7854 , the watershed will be more elongated [19]. The higher Rf values indicate of circulated shape. Thus, the form factor ranges between 0.35 for sub-watershed DTA71 to 0.62 for sub-watershed DTA46, which is the sub-watersheds in the study area indicate extend shape and shows lower peak flows of longer duration.

\subsubsection{Length of overland flow (Lof)}

Overland stream shows the distance of rainwater runoff on the surface before it gets in definite flow channels and it equals to middle of mutual drainage density [17]. The smaller Lof value indicating high runoff in the watershed and more susceptible to the flash flooding [15]. The overland flow aimed at the sub-drainage basin varies from $0.79 \mathrm{~km}$ for subdrainage DTA66 and $2.61 \mathrm{~km}$ for sub-drainage DTA11.

\subsubsection{Texture ratio $(T)$}

The texture ratio (T) shows the number of flow sections of the orders each boundary from that area [17]. The Text ratio is distinct of the most important concept of geomorphology that brings the relative spacing of drainage lines.

The capacity of the infiltration is the most significant factor that affects the drainage system and the assumed drainage system to include drainage density and drainage frequency [17].

The texture ratio was classified into five categories by Smith [20]. The value below 2 indicates very coarse texture, while coarse texture has value above 2 and below 4, moderate texture has a value of 4 until 6 , fine texture has value of 6 until 8 and value more than 8 is classified as very fine. Research area has texture ratio value between 0.22 (DTA 51) to 1.83 (DTA 63). The research area are watershed is dominated by a very coarse texture ratio. Means the properties of the drainage basin is relatively homogeneous, resistant, high infiltration has good soil permeability and low relief.

\subsection{Slope}

Slope is unique aspects directing the infiltration of groundwater and the runoff speed into the ground. In the slope categorized as gentle, the rainwater has slowly runoff on the surface and needs additional time for the water to get in (percolate) and indicates more infiltration, at the same time high slope simplify the high runoff, minor residence time for rainwater and facilitates infiltration.

A slope map of the research area was set from satelite data (ASTER DEM 10m resolution) utilizing the tool in Softwara GIS. Map of the slope area as shown in Fig. 2, explains that it varies

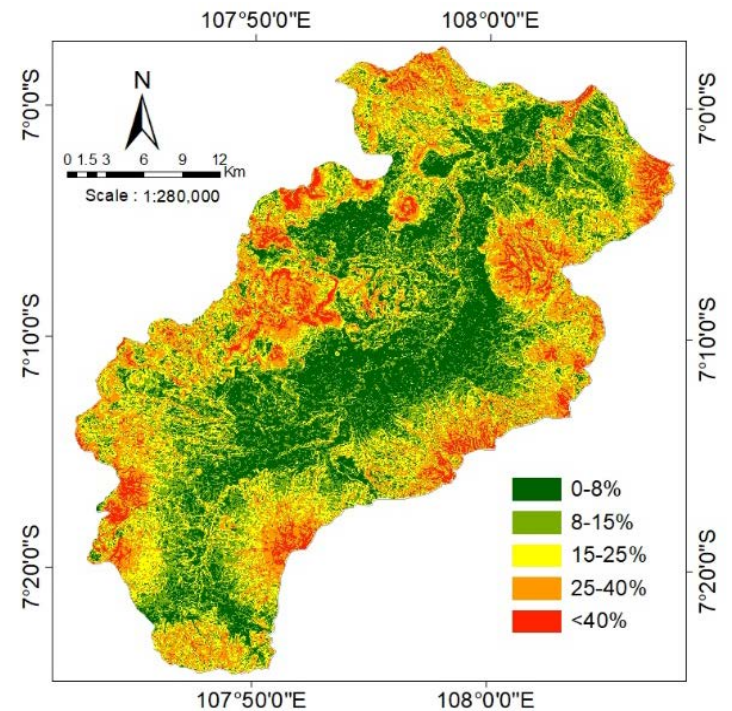

Fig. 2. Slope Map

between 2 - 28\%. The slope was categorized into seven distinct categories, i.e. 0-8\%, 8-15\%, 1525\%, 25-40\%, and more than $40 \%$. The main study of area occupies a slope category of $15-40 \%$ because of the appearance of hills and mountains, indicating high infiltration, surface runoff, and susceptibility of erosion.

\subsection{Rainfall}

Rainfall data were obtained from 6 weather stations belonging to Water Resources Management

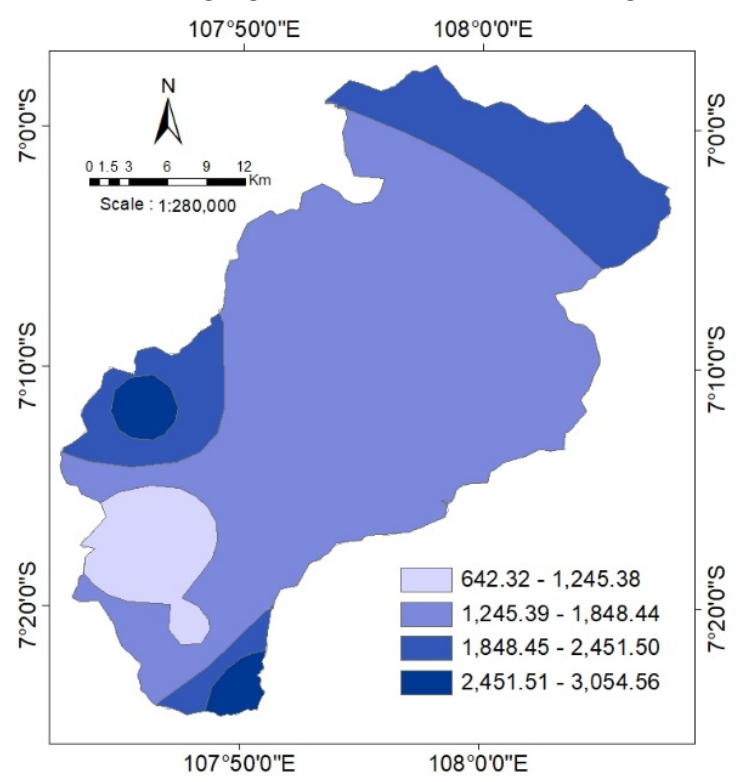

Fig. 3. Rainfall Map

Agency of the West Java Province, Indonesia. Inverse Distance Weighted (IDW) method was used to the rain distribution map from these data. The results of this interpolation shows in Figure 3. Mean yearly rain in Cimanuk watershed is $1709 \mathrm{~mm}$ and high rainfall values are received from November to 
February months.

The upper catchment area of Cimanuk Watershed in Garut city which obtains input from three plateaus, there is Mount Guntur in the north part, Mount Cikurai in the eastern part, and Mount Papandayan in the western part. Accumulation of rainfall concentrated in this watershed causes the volume resulted is huge.

\subsection{Land Use}

Land use change contributes greatly to the rising quality and quantity of floods. Therefore, land use became one of the parameters in this study. LANDSAT ETM+ was used to bring out a land use map of Sept 2019 then processed using ArcGIS software by applying the Maximum possibility classifier of classification. The image was classified into 5 distinct classes of land use. The distinct were forested area, paddy field, plantation, shrubs, and settlements. The results of processing can be seen in Figure 4.

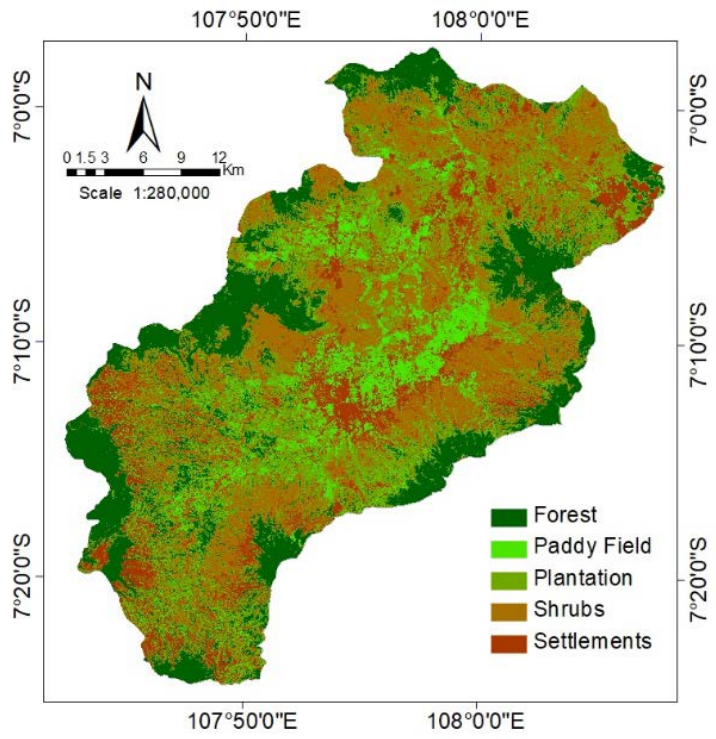

Fig. 4. Land use Map

Land use change of Cimanuk watershed of the upper catchment area with the heavy rainfall which is thought to be one of the causes of the flood in Garut City [3]. The area of Cimanuk watershed is predominantly used as agricultural lands and plantations.

Table 2. Land use analysis of the study area

\begin{tabular}{ccc}
\hline Land use Category & \multicolumn{2}{c}{ Area } \\
\cline { 2 - 3 } & (Sq. km) & (\%) \\
\cline { 2 - 3 } Forest & 239.71 & 20.44069 \\
Shrubs & 350.61 & 29.89742 \\
Paddy field & 111.19 & 9.481457 \\
Plantation & 311.53 & 26.56496 \\
Settlements & 159.67 & 13.61547 \\
\hline
\end{tabular}

\subsection{Morphometric Classification of Sub- watersheds}

Morphometric properties previously calculated are sorted by it's relationship to probability $[11,19]$ of rock material. The assignment of rank for each watershed depending on values of the morphometric parameters was considered to identify the priority setting of sub-watershed based on morphometric analysis.

The linear parameter has a direct connection with probability, the more value, the more credibility $[11,19]$. The density of watershed (Dd), the ratio of bifurcation (Rb), and the ratio of texture (T) value are classified from the highest value to lower value. While overland flow length (Lof), the ratio of elongation (Re) and factor of form (Rf) values are classified from the lowest value to the highest value.

After each parameter is classified, the compound parameter (Cp) summarised those values by calculating all categorized parameter. Refer to Eq. (1), the result of Cp calculation creates a range of Cp value that categorized into three categories :

(i) Priority basin (153.00 - 218.33)

(ii) Medium priority basin $(218.34-283.67)$

(iii) Low priority basin (283.68-349.00)

Out of 84 sub-watersheds, 25 sub-watersheds (29,8\% of the total sub-watersheds) were determined as the first priority, as they have low compound (Cp) values. There are 28 subwatersheds (33.3\% of the total sub-watersheds) fall under medium, with moderate compound (Cp) values, the remaining 31 sub-watersheds (36.9\% of the total sub-watersheds) were determined as low priority as shown below Figure 5. It has a high

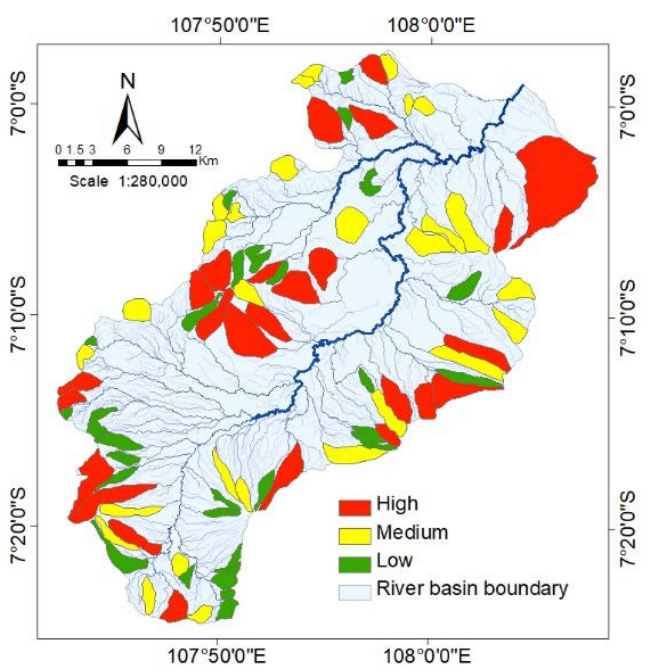

Fig. 5. Priority sub-watersheds based on morphometric 
compound (Cp) values, demonstrated in Table 3. Table 3. Priorities of sub-watersheds based on morphometric parameter

\begin{tabular}{|c|c|c|}
\hline \multicolumn{3}{|c|}{ Priority } \\
\hline $\begin{array}{c}\text { High } \\
(153.00-218.33)\end{array}$ & $\begin{array}{c}\text { Medium } \\
(218.34-283.67)\end{array}$ & $\begin{array}{c}\text { Low } \\
(283.68-349.00) \\
\end{array}$ \\
\hline $\begin{array}{l}\text { DTA04, DTA12, } \\
\text { DTA13, DTA20, } \\
\text { DTA22, DTA30, } \\
\text { DTA32, DTA34, } \\
\text { DTA35, DTA38, } \\
\text { DTA43, DTA44, } \\
\text { DTA48, DTA49, } \\
\text { DTA50, DTA52, } \\
\text { DTA53, DTA56, } \\
\text { DTA58, DTA61, } \\
\text { DTA70, DTA71, } \\
\text { DTA75, DTA77, } \\
\text { DTA81 }\end{array}$ & $\begin{array}{l}\text { DTA01, DTA06, DTA09, } \\
\text { DTA11, DTA14, DTA17, } \\
\text { DTA18, DTA27, DTA31, } \\
\text { DTA37, DTA39, DTA40, } \\
\text { DTA45, DTA47, DTA55, } \\
\text { DTA62, DTA63, DTA64, } \\
\text { DTA66, DTA67, DTA68, } \\
\text { DTA69, DTA74, DTA78, } \\
\text { DTA79, DTA80, DTA83, } \\
\text { DTA84 }\end{array}$ & $\begin{array}{l}\text { DTA02, DTA03, DTA05, } \\
\text { DTA07, DTA08, DTA10, } \\
\text { DTA15, DTA16, DTA19, } \\
\text { DTA21, DTA23, DTA24, } \\
\text { DTA25, DTA26, DTA28, } \\
\text { DTA29, DTA33, DTA36, } \\
\text { DTA41, DTA42, DTA46, } \\
\text { DTA51, DTA54, DTA57, } \\
\text { DTA59, DTA60, DTA65, } \\
\text { DTA72, DTA73, DTA76, } \\
\text { DTA82 }\end{array}$ \\
\hline
\end{tabular}

\subsection{Ranking of Sub-watersheds Based on Land Use}

The land use categories i.e., settlement, paddy field, shrub, agriculture and forest in all the 84 subdrainage basin are measured for the ordering of subdrainage basin based on land use modification investigation. Respectively class of land use was transformed in proportion area and grade basis on the area. On category settlements, paddy field, shrubs, and plantation, the highest percentage was ranked for 1 and the least value was valued last in the rank.

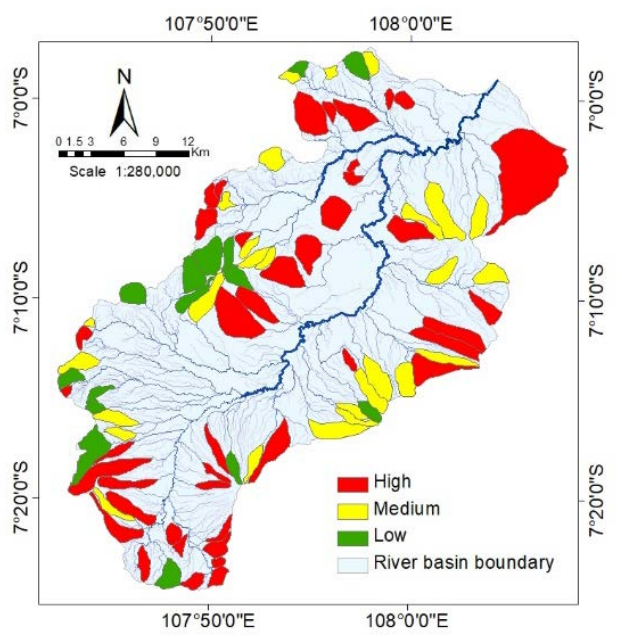

Fig.6 Priority sub-watersheds based on land use

Conversely, the smallest percentage on category forest is valued as rank 1 and the first point remained valued preceding in the rank. Lastly, the respectively grade land use class was build up to reach a compound (Cp) value. The priority was established by classifying of Cp value into three classes. Based on Eq. (1), first is high $(80-177)$, then medium (178 - 275) and last is low (276-372).

From the land use major analysis, Table 4 shows there are 42 sub-watersheds $(50 \%$ of the total subwatersheds) fall in the priority, 27 sub-watersheds (32\% of the total sub-watersheds) fall in medium priority, and 15 sub-watersheds (18\% of the total sub-watersheds) go down in low priority category as shown in Figure 6.

Table 4. Urgencies of sub-watersheds based on land use examination

\begin{tabular}{lc}
\hline & Priority \\
\hline $\begin{array}{c}\text { High } \\
(80-177)\end{array}$ & $\begin{array}{c}\text { Medium } \\
(178-275)\end{array}$ \\
$\begin{array}{l}\text { Low } \\
(276-372)\end{array}$ \\
\hline DTA01, DTA02, DTA03, DTA11, DTA19, DTA23, DTA04, DTA18, \\
DTA05, DTA06, DTA07, DTA24, DTA27, DTA28, DTA22, DTA25, \\
DTA08, DTA09, DTA10, DTA29, DTA31, DTA32, DTA26, DTA30, \\
DTA12, DTA13, DTA14, DTA34, DTA36, DTA40, DTA43, DTA47, \\
DTA15, DTA16, DTA17, DTA41, DTA44, DTA46, DTA51, DTA52, \\
DTA20, DTA21, DTA33, DTA50, DTA56, DTA57, DTA53, DTA54, \\
DTA35, DTA37, DTA38, DTA59, DTA64, DTA68, DTA55, DTA81, \\
DTA39, DTA42, DTA45, DTA69, DTA70, DTA74, DTA83 \\
DTA48, DTA49, DTA58, DTA80, DTA82, DTA84 \\
DTA60, DTA61, DTA62, \\
DTA63, DTA65, DTA66, \\
DTA67, DTA71, DTA72, \\
DTA73, DTA75, DTA76, \\
DTA77, DTA78, DTA79
\end{tabular}

\subsection{Ranking of Sub-watersheds of Flood Hazard}

The final results of the assessment of flood hazard depending on morphometric and land use analysis parameters remained linked to discover the communal sub-watersheds considered each priority.

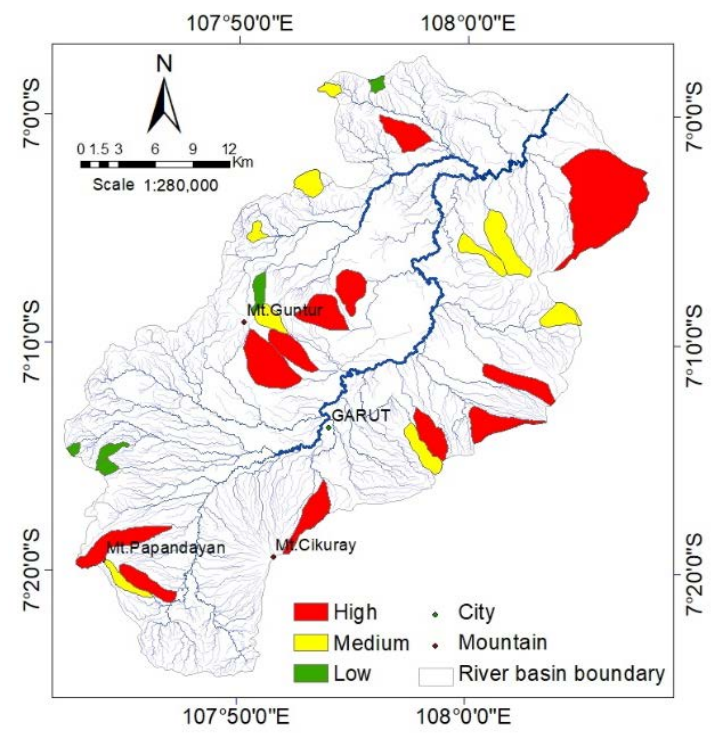

Fig.7 Final prioritization maps of flood hazard

The relationship displays that 26 sub-watersheds are joint sub-watersheds in the significance classes which are high, medium, and low. 12 sub-drainage basin considered as priority, 9 sub-watersheds fall in medium priority, and 5 sub-watershed go down in low priority (Table 5).

Table 5. Priorities of sub-watersheds on Upper Cimanuk Watershed

\begin{tabular}{ccc}
\hline & Priority \\
\hline High & Medium & Low \\
\hline
\end{tabular}


DTA12, DTA13, DTA20, DTA11, DTA31, DTA40, DTA25, DTA26, DTA32, DTA35, DTA38, DTA55, DTA64, DTA68, DTA42, DTA54, DTA48, DTA49, DTA58, DTA69, DTA74, DTA84 DTA82 DTA61, DTA71, DTA77

The results of the precedence of the sub-watersheds map based on morphometric and land use analysis are shown in Figure 7 . The priority spreads throughout the study area, dominates surrounding in Mount Guntur with average annual rainfall of 1245 to $1848 \mathrm{~mm}$ (high rainfall), dominates by steep slope $25-40 \%$ and land use by shrubs and plantation.

\section{CONCLUSION}

The result show study has found that 26 subwatersheds are communal sub-drainage basin based on morphometric and land use examination. Therefore, these areas must be specified the uppermost significance for soil and water preservation actions for anticipating on flooding.

The results of the research show that the average annual rainfall of 1245 to $1848 \mathrm{~mm}$ (high) with a slope of the study area dominates by $15-40 \%$ (high). Meanwhile, land use dominates by shrubs (29.88\%) and plantations (26.55\%), the slope of the watershed dominated by $15-40 \%$ (high), the drainage density of 3.3 (medium), the shape of the watershed $(\operatorname{Re} 0.775)$ with a somewhat oval or elongated shape and a very coarse drainage texture (0.22-1.83). High rainfall and steep slopes cause a greater flow of water and runoff with land use dominated by agricultural land is thought to be one of the main causes of floods in Garut city.

The implementation of GIS and remote sensing in morphometric and land use examination can offer significant value in estimating sub-drainage basin features and check the effectiveness of this method in the ordering of the upper Cimanuk Watershed the concerning to flash flooding.

\section{ACKNOWLEDGMENTS}

This paper is part of Doctoral research at Universitas Padjadjaran. The writers would like to utter his sincere appreciation to the Faculty of Geology, UNPAD and also would like thank to my colleagues for their contribution and help especially during the fieldwork for data collection. The positive comments and ideas of the arbitrators and and ideas of the arbitrators and publishing supervisor of GEOMATE are gratefully accredited.

\section{REFERENCES}

[1] Sukiyah E., Sunardi E., Sulaksana N., and Raditya R. P., "Tectonic Geomorphology of Upper Cimanuk Drainage Basin, West Java, Indonesia,” International Journal on Advanced Science, Engineering and Information Technology, vol. 8, no. 3, 2018, pp. 863-69.

[2] Muslim D., "Susceptibility of Landslide in the Forest Region of the Cimanuk River Catchment Area , West Java," Bulletin of Scientific Contribution, vol. 7, no. 2, 2009, pp. 145-51.

[3] Savitri I. B. and Pramono, "Upper Cimanuk Flood Analysis of 2016,” Journal of Watershed Management Research, vol. 1, no. 2, 2017, pp. 97-110.

[4] Hani1 A. W. A., "Pattern and Evaluation of Land Use in Cinangka Buffer Zone, Upper Cimanuk Sub Watershed," Journal of Watershed Management Research, vol. 2, no. 1, 2018, pp. 61-72.

[5] Sukiyah E., Syafri I., Sjafrudin A., Nurfadli E., Khaerani P., and Dian P. A. S., "Morphotectonic and satellite Imagery Analysis for Identifying Quaternary Fault At Southern Part of Cianjur-Garut Region, West Java, Indonesia,” ACRS 2015 - 36th Asian Conference on Remote Sensing: Fostering Resilient Growth in Asia, Proceedings, 2015, pp. 1-10.

[6] Agarwal C. S., "Study of Drainage Pattern Through Aerial Data in Naugarh Area of Varanasi District, U.P.,” Journal of the Indian Society of Remote Sensing, vol. 26, no. 4, 1998, pp. 169-75.

[7] Strahler A. N. and Chow V. T., "Quantitative Geomorphology Of Drainage Basins And Channel Networks," Handbook of Applied Hydrology, McGraw Hill Book Company, Jan. 1964.

[8] Horton R. E., "Erosional Development of Streams and Their Drainage Basins: Hydrophysical Approach to Quantitative Morphology.” Bulletin of the Geological Society of America, vol. 56, 1945, pp. 275370.

[9] Khan M. A., Gupta V. P., and Moharana P. C., "Watershed Prioritization Using Remote Sensing and Geographical Information System: A Case Study from Guhiya, India. 2001, pp. 465-75.

[10] Strahler A. N., "Quantitative Geomorphology of Drainage Basin and Channel Networks." Handbook of Applied Hydrology, vol. 63, 1964, pp. 439-76.

[11] Nooka Ratnam K., Srivastava Y. K., Venkateswara Rao V., Amminedu E., and Murthy K. S. R., "Check Dam Positioning by Prioritization Micro-Watersheds Using SYI Model and Morphometric Analysis - Remote Sensing and GIS Perspective.” Journal of the Indian Society of Remote Sensing, vol. 33, no. 1, 2005, pp. 25-38.

[12] Schumm S. A., "Evolution Of Drainage Systems And Slopes In Badlands At Perth 
Amboy , New Jersey.” Geological Society Of America Bulletin, vol. 67, no. 5, 1956, pp. 597-646.

[13] Varade A. M., "Morphometric Analysis of Dhaneri Watershed, Gambhar River Basin , Himachal Morphometric Analysis of Dhaneri Watershed, Gambhar River Basin, Himachal Pradesh , India.” Journal OfGeosciences Research, vol. 3, no. 1, 2018, pp. 59-65.

[14] Kingma, N. C., "Geomorphological Aspects Of Flood Hazard.” ITC, The Netherlands, 1991,

[15] Kumar Rai P., Narayan Mishra V., and Mohan K., "A Study of Morphometric Evaluation of the Son Basin, India Using Geospatial Approach.” Remote Sensing Applications: Society and Environment, vol. 7, Elsevier B.V., Aug. 2017, pp. 9-20.

[16] Prasad V., Mondal R.K., Banerjee N.C., Nandakumar P., and Singh, "Deciphering Potential Groundwater Zone in Hard Rock through the Application of GIS." Environmental Geology, vol. 55, 2008, pp. 467-75.
[17]Horton R. E., "Erosional Development of Streams and Their Drainage Basins: Hydrophysical Approach to Quantitative Morphology.” Bulletin of the Geological Society of America, 56, 1945, pp. 275-370.

[18] Obi Reddy G. P., Maji A. K., and Gajbhiye K. S., "Drainage Morphometry and Its Influence on Landform Characteristics in a Basaltic Terrain, Central India - A Remote Sensing and GIS Approach.” International Journal of Applied Earth Observation and Geoinformation, vol. 6, no. 1, 2004, pp. 1-16.

[19] Javed A., Yousuf M., and Rizwan K., "Prioritization of Sub-Watersheds Based on Morphometric and Land Use Analysis Using Remote Sensing and GIS Techniques. no. June, 2009, pp. 261-74.

[20] Smith K. G., "Standards for Grading Texture Of Erosional Topography,” American Journal of Science, vol. 248, no. 9. September 1950, pp. 655-668.

Copyright (C) Int. J. of GEOMATE. All rights reserved, including the making of copies unless permission is obtained from the copyright proprietors. 